\title{
Health of Tribal Women in India- Need For a Progressive Vision
}

\author{
${ }^{1}$ VIT School of Law-Vellore Institute of Technology Chennai, India \\ ${ }^{2}$ Chennai Dr Ambedkar Government Law College, Pudupakkam \\ ${ }^{3}$ VIT School of Law-Vellore Institute of Technology Chennai, India. \\ *Corresponding author. Email prema.e@vit.ac.in
}

E.Prema ${ }^{1, *}$ V. Shyam Sundar ${ }^{2}$ P.R.L. Raja Venkatesan ${ }^{3}$

\begin{abstract}
India, a country known for its tradition and ancient practices, always respects women. Due to technological development, maintaining such tradition in all aspects is a challenge. Technological development has always influenced society and contributed to its welfare. Many social evils like sati, the status of widows, and chila marriage impacted society, especially, few kinds of violence against women had been wiped-out by effective legislations. Gender discrimination endures in all countries despite its economic status. Centuries ago the society was civilized, and people are well educated. When it comes to the status of women, gender-based discrimination exists. The tribal women, compared to other Indian women, are decades behind. These tribal women encounter two important issues, discrimination based on gender few traditional practices that are dangerous for their health. India had enacted progressive legislations like The Scheduled Tribes and other Traditional Forest Dwellers (Recognition of Forest Rights) Act, 2006 but the question is how far this Act has the potential to provide opportunities to tribal women is unanswered. The Constitution of India provides certain protection to Tribes, but the protection and progress of tribal women are always in question. The government contends that the policies and schemes are provided for the growth and development of tribal women, but the societal certitudes do not permit the growth of tribal women. Internationally, the right to health is also assured in human rights treaties which State parties adopt and the principles are executed in their respective domestic laws. In this way, the States are obligated to provide the right to health as a basic right that is provided without any kind of discrimination, and if violated, the states are accountable before the law. The purpose of the study is to focus on the health conditions of tribal women in India. In addition to this, the obligation of States under international law regarding the protection of health under the right to health of tribal (indigenous) women has been discussed. The landmark judgments have been cited in order to focus on the existing health conditions of tribal women.
\end{abstract}

Keywords : gender discrimination, health, indigenous people, tribal women.

\section{INTRODUCTION}

India consists of a diverse group of people yet united. United, even in gender discrimination that prevails in the Indian societies. As per the 2011 census, India consists of 84.51 million people. The tribes are spread all over India, and there are 499 tribes and sub-tribes. Apart from caste and religionbased discriminations, gender-based discrimination sways the growth of women in India. Additionally, the situation of tribal women is quixotic. It is undeniable the Indian Constitution and few legislations give protection to the tribal women but their status compared to other community women is not progressive. There are many disadvantaged socio-economic groups in India. The Scheduled Tribes, particularly,women, suffer a lot. In the international arena, the women tribes of India had achieved in many sectors like the case of best practices was achieved by tribal women in the Kandhmal district Odisha.[1] Across India, there are about 705 ethnic groups who are notified as Scheduled Tribes. According to the last 2011 census, India comprises 104.3 million people, out of which the Scheduled Tribes comprise 8.6 percent of the total population. In the Declaration on Rights of Indigenous People, 2007, India voted in favourof it but did not consider the term "indigenous people". 
This comprehensive international instrument is a great initiative by the world nations in protecting the growth and development of the indigenous community in addition to guarantee the minimum standards for the survival, dignity, and well-being of the indigenous peoples of the world [2]

Historically, tribal women also participated in wars against the Britishers in India. Rani Durgavati, Rani Gaidinliu, and Rani Chennamma confronted the British troops.[3] This shows how healthy tribal women were. Health is a prime concern for every human being. Health is also a basic human right. Nearly $90 \%$ of tribes in India live in rural areas, and due to ignore, they face many health-related issues. The tribal population in India, nearly half of them lives in poverty. It is also found that the young tribal girls get married at a very early age and confront higher health risks due to frequent pregnancies, unsafe delivery, and undernourishment. In 2013, the Expert Committee on Tribal Health was jointly formed by the Ministry of Health and Family Welfare and the Ministry of Tribal Affairs. It is the first comprehensive committee of its nature that projected the health of tribes. Malnutrition and communicable disease are few issues that are confronted by tribal women, which led to child mortality. The Expert Committee pinpointed the tena issues of the tribal as health burdens, where women are more vulnerable. They are as follows: [4]

i) The health problems relating to maternal and child issues of communicable diseases continue to prevail;

ii) There was an increase of noncommunicable diseases like mental stress and addiction;

iii) Injuries as a result of violence in conflict situations, snakes, and animal bites were prevailing;

iv) As a result of geographic terrain and harsh environments due to difficult natural condition, the tribes suffered

v) The social-economic factors like education, income, housing, water, and sanitation were worse;

vi) The standards of healthcare services and access of health care were found poor and with low access and coverage;

vii) There were no trained and skilled health professionals as they were unwilling to serve in tribal areas and at all level, many constraints in health resources;

viii) In most of the states, there were not enough funds allocated for tribal health;

ix) Very importantly, there is a lack of data, monitoring, and evaluation that covers the abovementioned issues;

Critically, the political disempowerment of tribal problems from individual to the national level,aggravates the above issues. The participation in decision making and inclusion of tribal in the planning are less in political empowerment.

\section{RESEARCH METHOD}

This research is conducted as per existing judgments and legislations, which analyze both primary and secondary data. The primary data is any international conventions and regulations concerned the rights of tribal women. The documents from the United Nations and the relevant international agencies are referred for the purpose of comparative analysis regarding tribal women as primary data. The secondary data consists of books, journals, and other relevant materials relating to the health of tribal women.

\section{FINDINGS AND DISCUSSION}

There are problems dealing with the health of tribal women. They face difficulties getting medical facilities in the absence of proper infrastructure. Despite the fact that there are existing legislation and conventions for ensuring the rights of the tribal women,including the medical facilities, there are still issues with the proper medical facilities for tribal women. The main points for discussion are consolidated as the right to health Aspects for Tribal Women in India and State Obligation.

\subsection{Right to Health Aspects for Tribal Women in India}

Generally India lacks accessibility which impacts tribal wome, and they are unable to get medical help or go for institutional delivery. When it comes to women's health, maternity health will be throughout the pregnancy and post pregnancy. Firstly, for tribal women in India, the community practice delivery happens at home. Such delivery practice puts both the mother and the infant in danger. Secondly, the nutritional standard is 
important for women and children. It is widely noted to be unsatisfactory, and there were high cases of malnutrition [12]. Thirdly, due to lack of awareness, tribal women confront many communicable diseases like tuberculosis, skin infections, and HIV,. Fourthly, tribal women are anemic, and it is acute among pregnant women and lactating mothers [12]. One of the latest research by the M.S.Swaminathan Research Foundation states that the tribal community was responsibly protecting many valuable medicinal plants and conserving food-nutrition gardens in many parts of India.[14] But many tribal women and children in rural India are malnutrition because of poverty. The right to health is a guarantee under Article 21 of the Indian Constitution, 1950. In many landmark decisions, the Indian judiciary has established its power in the protection of the rights of common men. One of the landmark judgements by the High Court of Delhi in 2011 in Court on Its Own Motion Vs Union of India (W.P.5913/2010) proves how the Court brought public interest litigation on its own motion to protect the right of citizens, which is guaranteed under Article 21 of the Indian Constitution. It also reminded the state's duty to protect the rights of the poor pregnant women and children. A new paper report stated about a deprived woman who died on a busy street 4 days before she had given birth to a girl baby. The Court stated the it is the government's duty to protect the rights of pregnant women under the right to maternal health by ensuring the destitute women with proper shelter exclusively for pregnant and lactating women with medical aid and food. The Government of Delhi contended that such shelters already existed. But the Human Rights Law Network (HRLN), which was ordered by the Court to file an amicus brief on the conditions of the deprived women in Delhi, the Court found that the state and its fund under its programs did not have the capacity to meet the facilities which the Court's mandated. It was an appealing move by the Court. The pendency of the case orders the Delhi government to establish at least two shelter homes to benefit the destitute women with the necessary medical aid and food to protect these women from giving birth on the streets. But later in 2014 there was again another case Priya Kale v. NCT by the HRLN on behalf of a woman who lost her two months old daughter who was living in an overnight shelter for families. The fact finding mission revealed the condition of the sheltered balcony, which was exposed to harsh weather. In the Court on Its Own Motion v. Union of India (W.P.5913/2010), the Court also analyzed two important judgements of Laxmi Mandal Vs. Deen Dayal Harinagar Hospital\& Others (Delhi High Court 2008) and Jaitun v. Maternal Home, MCD, Jangpura \& Others (Delhi High Court, 2009). In these cases, the Court cited the provisions under the Universal Declaration of Human Rights, the Convention on the Elimination of All Forms of Discrimination Against Women, the International Covenant on Economic, Social and Cultural Rights, and General Comment 14 by the Committee on Economic, Social and Cultural Rights. The Court also further held that the government must ensure the right to health and reproductive rights under the Indian Constitution and the above said international human rights Bills.

Recent India's National Family Health Survey found that $46 \%$ of indigenous women and adolescent girls had, at least four antenatal care visits, compared to $61 \%$ of Hindu women and adolescent girls.[5] The tribal population suffers the triple burden of disease; in fact, it is quadruple, namely, communicable diseases, noncommunicable diseases, malnutrition, mental health, and addictions. $8.6 \%$ of the tribal population constitutes $30 \%$ of all malaria cases,> $60 \% \mathrm{P}$. falciparum, and $50 \%$ of the mortality associated with malaria. The estimated prevalence of TB (per 100,000) was 703 cases against 256 in the nontribal population. Also, only $11 \%$ of pulmonary TB gets treated based on smear positive reporting (Remember End TB Strategy 2025 goals in India). The proportion of new leprosy cases was found to be $18.5 \%$ (India declared to have reached the WHO target of elimination as a public health problem, less than 1/10,000 cases by the end of 2005). The percentage of children underweight is $42 \%$ and about $77 \%$ of children under five year old are anemic. It has been reported that malnutrition and child deaths are in spurts, reported mostly during rainy seasons. Almost 50\% of adolescent ST girls have BMI less than 18.5 , and about $65 \%$ of tribal women (15-49 years age) suffer from anemia (nontribal $47 \%$ ), a vicious cycle. More than $72 \%$ of tribal men 15-54 years of age use tobacco, and more than $50 \%$ consume alcohol against $56 \%$ and $30 \%$ nontribal men, respectively. [6,7,8,9,]. There are deep-rooted cultural chasms between tribal groups and the largely nontribal health care providers, resulting in insensitive, dismissive and discriminatory behavior on the part of health care personnel. It is also important to note here that tribal people are facing language barriers while accessing health, even by urban populations of the same state. [10] 


\subsection{Health Care and the State Obligation}

It is a duty of a nation to provide healthcare services, including access to health. India had adopted the United Nations Sustainable Development Goals, 2015, and is committed towards the Universal Health Care and Universal Health Assurance.[11] The Universal Declaration of Human Rights, 1948 under Article 25 emphasizes the recognition of the rights of all persons to an adequate standard of living which includes the right to health. Article 12 of the Convention on the Elimination of All Forms of Discrimination Against Women, emphasizes the States' obligation to eliminate any discrimination against women, specifically in health care and health care services. Additionally, the states are obligated to ensure women appropriate services in regards to pregnancy, adequate nutrition during pregnancy, lactation, and free services required in this regard.

Health must be understood as one of the essential components of an adequate standard of living. Further, the United Nations Declaration on the Rights of Indigenous People, 2007 (UNDRIP) is a framework that protects indigenous people from discrimination. This creates an obligation upon the governments to ensure that indigenous communities must be treated in the same way as the other citizens, irrespective of sex, caste, religion. There are specific provisions under UNDRIP that discussesmental and physical health. They are as follows: [12]

i. Article 17.2 which obligates the States cooperating with indigenous communities to initiate specific measures for protecting indigenous children from economic exploitation, not involved in any work that is hazardous or interferes with education, or harmful to children,s health.

ii. Article 21.1 provides the right to indigenous people without discrimination to develop their economic and social conditions, including sanitation and health. Here the state is under an obligation to provide health care facilities equally to all people whether they live in rural are city areas.

iii. Article 23 explains the right of the indigenous people to determine and develop priorities and strategies for implementing their right to development which includes health rights. The states have an obligation to create health facilities and policies that help the indigenous people achieve their health standards.

iv. Article 24.1 is very significant. The right to traditional medicines and maintain their health practices is guaranteed under this provisoon as in many tribal communities; they follow separate medicines and the usages of such resources available from nature around them. Here the state must protect such knowledge from exploitation or misuse by others. The government has an obligation to provide the vital medicinal plants,animals, and minerals that belong to the indigenous community. Article 24.2 guarantees the rights of indigenous communities to enjoys the highest attainable standards of physical and mental health, and the state must initiate with required steps to achieve the absolute realization of this right.

v. Article 29.3 obligates the States to take effective measures to ensure with the necessary programs, policies that facilitates, monitor and maintain the health of indigenous communities.

The above explained are the international health standards (minimal) that are imposed on the States under state obligations that must be achieved with full potential for the welfare of women.

\section{CONCLUSION}

Based on the above discussion, the following points have been discussed in the conclusive part in order to focus on the problems faced by the tribal women regarding health care. The tribal women contribute to the protection and preservation of natural resources. In India, many of the tribal communities live inside the Reserved Forests Areas. These forest dwellers involve in protecting the forest resources. Men from tribal communities in few areas have opportunities to associate with nontribal societies for education and employment reasons, but the tribal women are still not allowed to move out of the tribal communities. There are many reasons like the absence of schools and higher educational institutions, lack of transportation, and lack of health care facilities. Thus, the tribal community does not encourage women to go out from their respective areas. Many NGOs are working specifically to provide health facilities to the tribes living in remote India. But still, the issues relating to health in the tribes 
persist. India is progressively considering the protection of indigenous women in all aspects, but meeting the international standards is required. The tribal communities in India, especially tribal women, contribute to food production and preservation of medicinal plants. There are also international initiatives that protect and encourage tribal women. Participation of tribal women in the decision-making process in the international arena has notably increased, but the basic rights are yet to be protected at the domestic level. India must concentrate on protecting the health rights of tribal women who are vulnerable by providing them with standard healthcare and access to the healthcare system. It can be understood in the extensive study that the tribal areas generally are rich in resources like, pure and clear water and medicinal plants. This condition is not found in every part of tribal areas. The ignorance and unawareness of health care required in the presence era have contributed to the setback in the health of tribal women. For example, hygienic practices which have to be followed at the time of mensuration and childbirth are lacking in tribal women. The infections that affect the female genital tract, problems in ovaries, and genetic disorders are mostly unknown to the tribal communities, and special awareness is required. Language is also a big issue because some few tribes have a unique language while making them understand the health requirements or raising awareness is sometimes difficult. Diagnoses at child birth or any genetic diseases that affect a child in the womb, pre-diagnosing diseases like breast and cervical cancer are essential for women's health. They are hindered by the traditional practices and superstitious beliefs of the tribes. Education for the tribal communities, which potentially includes and motivates the tribal women in the professional courses, will enhance the health, social and economic status. Conclusively, the governments have to bridge the gap between the health of tribal women and non-tribal women especially regarding their nutritional standards and health care awareness. The Government of India should allocate more funds to provide health care to tribal women and ensure uniform implementation through periodical checks. It is worthwhile to note here that right to health is a fundamental right of the citizens, but the right to health care to tribal women is also to be recognized in reality to ensure their fundamental rights.

\section{REFERENCES}

[1]. Tribal Women Farmers as "Change Agents" for Environmental Protection. Accessed: Oct. 12 2020. [Online]. Available: https://unfccc.int/climateaction/momentum-for-change/activitydatabase/tribal-women-farmers-as-changeagents-for-environmental-protection-india

[2]. United Nations Declaration on the Rights of Indigenous People. Accessed: Oct. 12, 2020. [Online]. Available: https://www.un.org/development/desa/indi genouspeoples/declaration-on-the-rightsof-indigenous-peoples.html

[3]. Adivasi Lives Matter, 3 Tribal Women Who Helped Make India a Republic. February 2020. Accessed: Oct. 15, 2020. https://feminisminindia.com/2020/02/28/3tribal-women-helped-make-india-republic/

[4]. Available: http://tribalhealthreport.in

[5]. National Family Health Survey (2015-16). Government of India, Ministry of Health and Family Welfare. Accessed: Oct. 16, 2020. [Online]. Available: http://rchiips.org/nfhs/pdf/nfhs4/india.pdf

[6]. Executive Summary - Tribal Health Report, India. Accessed: Oct. 17, 2020. [Online].

Available: http://tribalhealthreport.in/exec utive-summary/

[7]. J. Narain, “'Health of tribal populations in India: How long can we afford to neglect?" Ind. J. Med. Res., vol. 149, p. 313, 2019.

[8]. K. Ghosh, R. B. Colah, and M. B. Mukherjee, "Haemoglobinopathies in tribal populations of India," Ind. J. Med. Res., vol. 141, pp. 505-508, 2015.

[9]. V. G. Rao, J. Bhat, R. Yadav, M. Muniyandi, R. Sharma, and M. K. Bhondeley, "Pulmonary tuberculosis-a health problem amongst Saharia tribe in Madhya Pradesh," Ind. J. Med. Res., vol. 141, pp. 630-635, 2015.

[10]. Accessed: October 18, 2020. [Online]. Available: https://www.worldbank.org/en/news/featur e/2012/02/28/improving-health-servicesfor-tribal-populations

[11]. Available: https://niti.gov.in/indias-commitment-tothe-sdgs. Accessed: October 19, 2020

[12]. Accessed: Oct. 19, 2020. [Online]. United Nations Declaration on the Rights of Indigenous People. Available: 
https://www.un.org/development/desa/indi genouspeoples/wp-

content/uploads/sites/19/2018/11/UNDRIP _E_web.pdf

[13]. Accessed: Oct. 19, 2020.

[Online]. Available: https://www.ohchr.org/Documents/Issues/I Peoples/EMRIP/Health/IndigenousWome nNetworkIndia.pdf

[14]. Accessed: Oct. 19, 2020. Available:

https://indiantribalheritage.org/?p=11066\# gsc.tab $=0$ 